\title{
Thermo-mechanical and stratigraphic numerical forward modelling: recent advances and their joint application in the Pannonian Basin
}

\author{
BalÁzs, Attila ${ }^{1}$, Matenco, Liviu² ${ }^{2}$ GranjeOn, Didier ${ }^{3}$
}

\begin{abstract}
${ }^{1}$ Laboratory of Experimental Tectonics, Department of Sciences, Università degli Studi Roma Tre, Rome, Italy ${ }^{2}$ Tectonics Group, Department of Earth Sciences, Utrecht University, Faculty of Geosciences, Utrecht, Netherlands ${ }^{3}$ IFP Energies Nouvelles, Department of Geology-Geophysics-Geochemistry, Rueil-Malmaison, France

Corresponding author: Attila Balázs (balatt@gmail.com)
\end{abstract}

\section{Tektonikai és rétegtani numerikus modellezés: együttes alkalmazásuk és új eredményeik a Pannon-medencében}

Összefoglalás

Üledékes medencék térben és idôben változó süllyedéstörténete jól tükrözi az egy adott területre jellemző fôbb medenceformáló klimatikus, üledékes és tektonikai folyamatokat. A klasszikus medenceanalízis módszere fúrási és további geofizikai adatokból, valamint az üledékes rétegsor megismeréséből származtatja egy medence süllyedéstörténetét. Napjainkra azonban különböző numerikus modellezési módszerek lehetővé teszik medencék süllyedéstörténetének és fácieseloszlásának számítását és előrejelzését, amennyiben ismerjük a terület fejlődését leíró főbb fizikai folyamatokat. Ezen folyamatorientált modelleket geológiai és geofizikai adatokkal kell hitelesíteni. Ebben a tanulmányban litoszféraléptékú tektonikai és medenceskálájú felszíni folyamatok kapcsolatát vizsgáljuk, amely megköveteli a különböző térbeli és időbeli skálájú numerikus modellek együttes alkalmazását. Ennek megfelelően ötvöztük a 2D termo-mechanikus Flamar tektonikai modellt és a nagy felbontású DionisosFlow rétegtani modellező programot, így képesek voltunk számszerúsíteni a kéreg és litoszféra rideg és képlékeny deformációjának és elasztikus meghajlásának léptékét. A tektonikus numerikus modell által számított süllyedéstörténetet bemenő adatként használtuk a rétegtani modellezésnél, ahol a fejlődő részmedencékben vizsgáltuk az üledékes szállítási útvonalak és az üledékes környezetek fejlődését. Ezzel egyidejúleg figyelembe vettük a vízszintváltozások és klimatikus hatások szerepét a medence süllyedés- és feltöltódéstörténetének szimulációja során. Aszimmetrikus litoszféra extenziós modelleredményeink jelzik mély félárkok fejlődését a medenceperemektől a medence belseje felé. Egy rövid kiemelkedési fázist követốen a „,posztrift” időszak további kilométer nagyságrendú differenciális vertikális mozgásokkal jellemezhető. Modellünk rávilágít a vízmélységértékek térbeli és idôbeli változékonyságára, valamit a kialakuló unkonformitások okaira. Modelleredményeink egy lehetséges forgatókönyvet jelentenek a Pannon-medence tektonikai és rétegtani fejlődésére.

Kulcsszavak: termo-mechanikus modellezés, rétegtani modellezés, Pannon-medence, extenzió

Abstract

Basin analysis and subsidence history provide key insights into sedimentary basin forming mechanisms. Direct observations have long been the only source of information on their thermal and lithological architecture. State of the art modelling techniques today enable the prediction and computation of their formation and evolution constrained by geological field observations, geophysical and deep borehole data. Understanding the inherent connections between largescale tectonic and local basin-scale surface processes requires the joint application of thermo-mechanical and stratigraphic modelling techniques. To this aim, we combined the thermo-mechanical lithospheric-scale numerical code Flamar and the high-resolution 3D deterministic stratigraphic software DionisosFlow. This joint modelling method quantifies forcing factors, such as crustal and lithospheric thinning, lithospheric flexure, sea-level and climatic variations associated with water and sediment influx and sediment compaction. The modelling shows the migration of extensional deformation in space and time creating deep half-grabens. After a rapid uplift event, the subsequent post-rift times are characterised by continuous kilometre-scale differential vertical movements. The modelled tectonic subsidence and uplift rates and halfgraben geometries are imported into the 3D stratigraphic modelling code. Our modelling of a $120 \mathrm{~km} \times 150 \mathrm{~km}$ area shows that such scenarios are associated with continental alluvial to shallow-water sedimentation and footwall erosion during the early stages of the syn-rift, followed by rapid deepening during the subsequent syn-rift evolution. Finally, the basins are filled by a large-scale prograding shelf-margin slope system during the post-rift times. We differentiate between unconformities caused by tectonics, sea-level variations or auto-cyclic processes. Our tectonic and stratigraphic results are compared with geological and geophysical constraints from the Pannonian Basin of Central Europe. 


\section{Introduction}

Extensional sedimentary basins cover large areas of the Earth and contain important geo-resources, such as geothermal energy. Understanding the tectonic and sedimentary processes that exert first-order control on their formation and evolution and quantifying their thermo-mechanical properties are important for understanding the dynamics of System Earth. Tectonic and stratigraphic numerical forward modelling has become universal tools for the analysis of large-scale lithospheric processes (BUROV 2007, GERYA 2010), the verification of previously proposed geological concepts (Burov \& PoliaKov 2001, GRANJEON 2014) and the prediction of basin-scale sedimentary architecture and 3D facies distribution (CsATó et al. 2013). Furthermore, such methods are widely used to better constrain the geological and geophysical observations or predict subsidence and thermal properties (FRANÇOIS et al. 2018, BALÁZs et al. 2017a).

The overall sedimentary architecture of extensional basins is the result of the balance between the rate of creating accommodation space and sediment supply (SCHLAGER 1993). Quantifying the distinct tectonic, climatic or other sedimentary processes and their feedbacks is a fundamental challenge in geosciences, because they all act on different spatial and temporal scales. The tectonic subsidence patterns of extensional basins are primarily controlled by crustal and lithospheric thinning, influenced by the rheological and thermal properties and by the rate and localisation of extensional strain. Furthermore, erosion and sedimentation, which are also controlled by climatic variations localise deformation, enhance hanging-wall subsidence and footwall exhumation (e.g. BIALAS \& BUCK 2009). Understanding this link between deep Earth and surface processes and bridging the gap between their scales necessarily requires an integrated approach.

The Pannonian Basin of Central Europe is an ideal case for the development and application of new basin modelling techniques, enabled by the available advanced knowledge on the formation and evolution of this region (HORVÁTH \& ROYDEN 1981). This basin was among the first natural laboratories where the classical extensional stretching model and their subsequent modifications have been applied (ROYDEN \& KeEN 1980, Sclater et al. 1980, HorvÁTH et al. 1988). These classical models are still used today in rift basins to decipher subsidence and thermal histories. However, recent modelling techniques and results (e.g. HORVÁTH \& CLOETINGH 1996, Burov 2007, Huet et al. 2011, BALÁZs et al. 2017a) demonstrated that asymmetric extensional basins formed in back-arc settings cannot be directly quantified by earlier analytical predictions of the classical McKenzie model (McKenZIE 1978, Royden \& KeEN 1980) and often shows anomalous subsidence patterns.

The continuous academic research and hydrocarbon exploration have resulted in a solid knowledge of (sub)surface geology, stratigraphy and sedimentology (JuHÁsz et al. 2007, Nagymarosy \& HÁmor 2012, Magyar et al. 2013,
SzTANÓ et al. 2013), crustal and lithospheric structure (TARI et al. 1999), the role of mantle dynamics (HORVÁtH \& FACCENNA 2011), the tectonic evolution (FODOR et al. 1999, Horváth et al. 2015, MATENCO et al. 2016, BALÁZs et al. 2017a) and thermal properties (LENKEY et al. 2002, BÉKÉSI et al. 2017) of the Pannonian Basin. Building on these observational data a one-way coupled tectonic and stratigraphic numerical forward modelling methodology is developed in this study to simulate and analyse the tectonosedimentary evolution of asymmetric extensional back-arc sedimentary basins, such as the Pannonian Basin. Our modelling results are compared with an interpreted reflection seismic profile from the Danube Basin part of the Pannonian Basin system.

\section{Numerical methods}

In this study we combined a large-scale thermomechanical tectonic and a high-resolution stratigraphic forward modelling approach (Figure 1) to investigate the mechanics of extension, tectonic subsidence and thermal history of extensional basins, as well as the evolution of sedimentary transport routes and facies distribution in the depocentres. The thermo-mechanically and thermo-dynamically coupled finite element code Flamar v12 (BUROV \& YAMATO 2008) based on the FLAC-Para(o)voz algorithm (CUNDAll 1989, PoliaKov et al. 1993) was used to assess the lithospheric and surface response to the fast extension of an initially thick and hot crust. In this study we used a one-way coupling method, i.e. at certain time steps, the tectonic vertical movement of the basement, i.e. basement subsidence rate and depocentre geometries are extracted from the thermo-mechanical model and is imposed in the subsequent 3D stratigraphic forward modelling with DionisosFlow (Figure 1). Flamar only uses a simplistic surface processes approach, the detailed and high resolution sedimentation and erosion is implemented in the subsequent DionisosFlow model, but in this study we only present a one-way coupling between these codes. The 2D vertical motions are uniformly extended in the third dimension and subsequently imported into the 3D stratigraphic modelling code. Both models use a dynamic timestep scheme, DionisosFlow uses a finer temporal resolution and therefore linear interpolation has been made between the time steps of the tectonic modelling code.

\section{Thermo-mechanical modelling}

Thermo-mechanical numerical modelling is particularly well suited to study the dynamics of lithospheric extension and related topographic response. We built our case on the continuation of earlier parametric studies on asymmetric lithospheric extension (BALÁzs et al. 2017a). The code Flamar locally solves full Newtonian equations of motion in a continuum mechanics approximation in 2D. The equations are coupled with the heat transfer and further constitutive 


\section{a) Thermo-mechanical modelling}

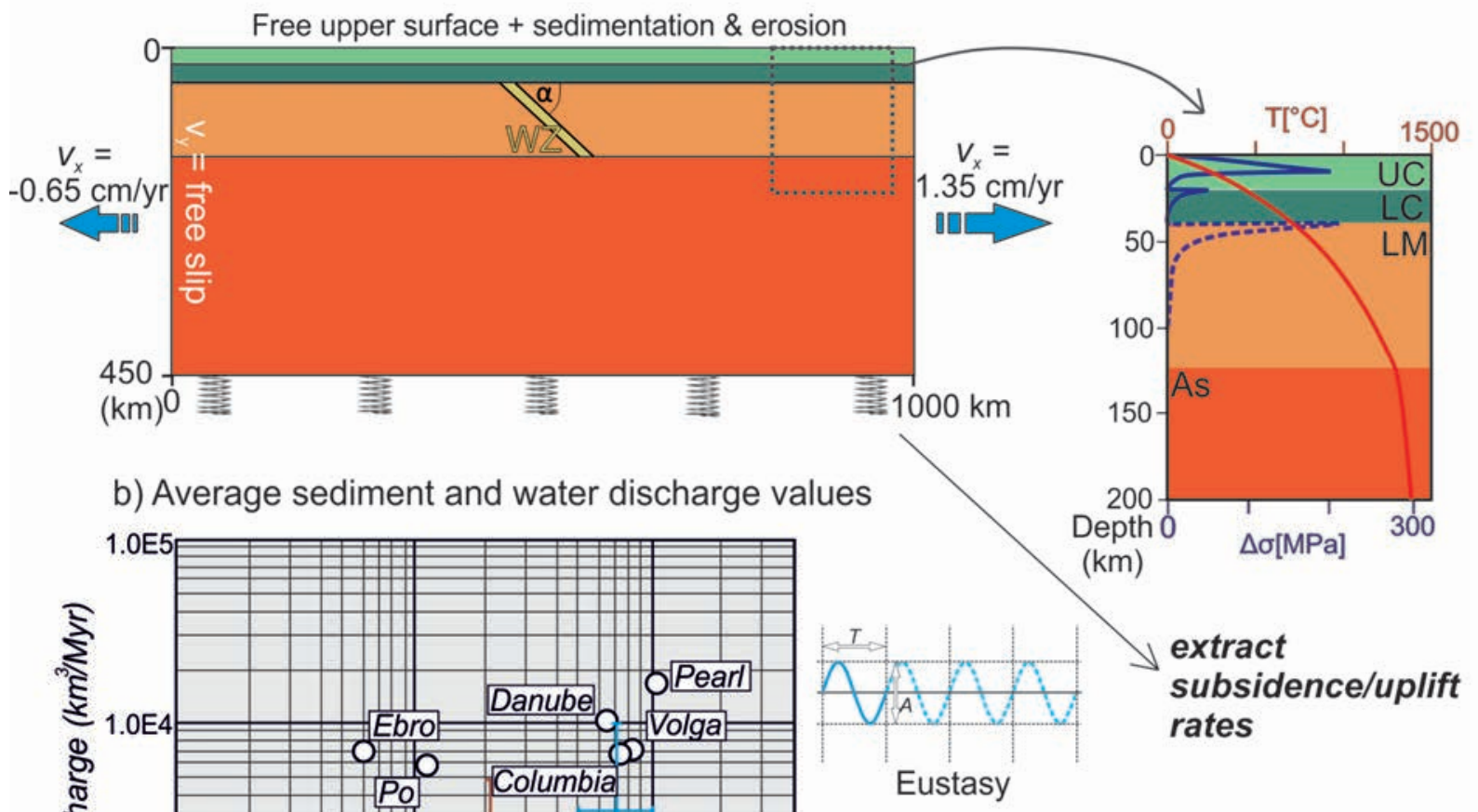

\section{c) Stratigraphic 3D forward modelling basement geometry}
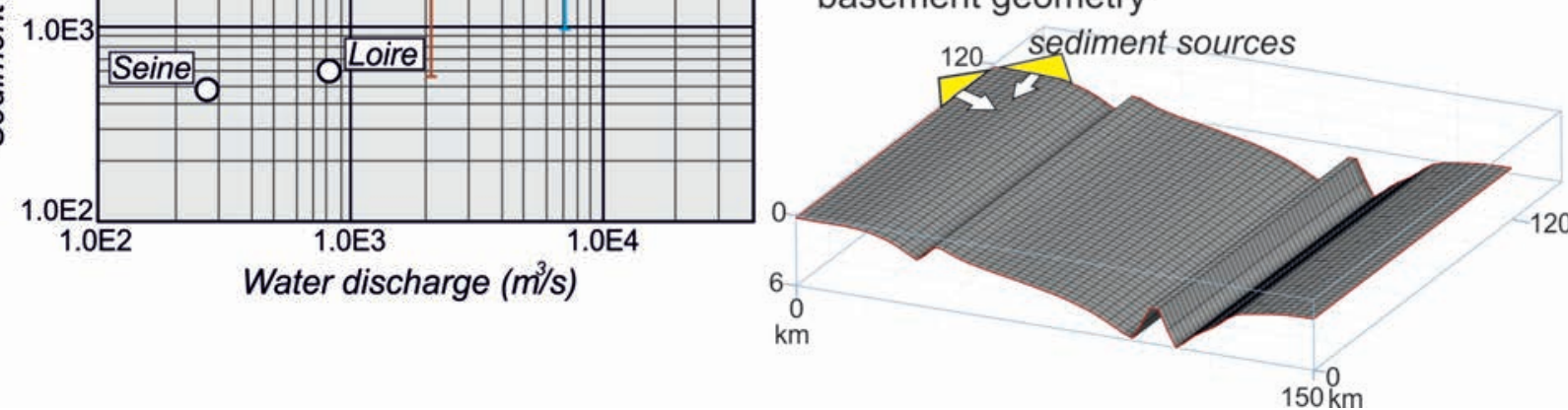

Figure 1. Initial setup of the thermo-mechanical and stratigraphic numerical models. (a) UC = upper crust, LC = lower crust, LM = lithospheric mantle, As $=$ asthenosphere. Constant lateral velocities are applied at the sides of the model (blue arrows). An initial tilted rheological weakness zone (WZ) is implemented in the lithosphere simulating a former suture zone. (b) Relation between sediment and water discharge based on observations from major rivers (modified after CSATó et al. 2014). Blue sign indicates values used in our stratigraphic forward modelling. (c) Basement geometry in sediment transport and deposition forward modelling of three half-grabens. The setup assumes $60 \times 48$ equally spaced cells with $2.5 \mathrm{~km}$ equal spacing. Water discharge and sediment flux sources are defined in the model corner

1. ábra. A tektonikus és rétegtani numerikus modellezés felépitése. (a) UC =felsö kéreg, $L C=$ alsó kéreg, $L M=$ köpenylitoszféra, As = asztenoszféra. A szinrift extenziót a modell oldalán definiált konstans sebességek reprezentálják. Egy reológiai gyengeségi zóna (WZ) reprezentál egy örökölt szutúrát a köpenylitoszférában. (b) Folyók üledék és vizhozamának kapcsolata mérések alapján (CSATó et al. 2014 alapján módositva). A kék kereszt a modellezés során vizsgált értékeket jelöli. (c) A rétegtani modellezés során használt geometria 60×48 elemre bontva 2,5 km horizontális felbontással. A víz és üledékforrás a modellterület sarkán definiált, egy külsö folyó torkolatát reprezentálva

equations, using temperature and pressure dependent densities and enabling the modelling of elastic, viscous and plastic deformation. This method handles a free upper surface affected by simplified surface processes, in terms of erosion and sedimentation, which are simulated by a linear diffusion law. Such an approach takes into account the smoothness of the surface (i.e. surface curvature) on the local erosion rate, the eroded material is deposited in the subsiding depocentres. Detailed description of this numerical scheme is available in prior studies (BUROV \& POLIAKOV 2001, Burov 2007, FrANÇOIS et al. 2013, 2018; KOPTEV et al. 2018).

Our setup used in this study (Table I) assumes a 1000 $\mathrm{km}$ wide and $450 \mathrm{~km}$ deep section (Figure 1, a). We defined a lithosphere of $90 \mathrm{Myr}$ thermo-tectonic age. We defined an initial configuration of a $135 \mathrm{~km}$ thick lithosphere including a $20 \mathrm{~km}$ thick quartz (RANALLI \& MURPHY 1987) dominated upper crust, $20 \mathrm{~km}$ diabase (CARTER \& TSENN 1987) lower crust and $95 \mathrm{~km}$ dry olivine (WILKS \& CARTER 1990) mantle overlying further $315 \mathrm{~km}$ deep asthenosphere of wet olivine rheology (CHOPRA \& PATERSON 1984). Similar to previous studies we defined a tilted weak zone in the lithosphere representing a suture inherited from a former subduction episode (BALÁzs et al. 2017a, 2018a). It is assumed that such former subduction and collisional phases have resulted in a 
Table 1. Parameters of the thermo-mechanical numerical experiment. Rheological parameters are adapted from similar numerical experiments. For details see text and BALÁzs et al. (2017a)

1. táblázat. Termo-mechanikus modellparaméterek. A módszer részletes leirása megtalálható korábbi tanulmányokban (pl. BALÁZS et al. 2017a)

\begin{tabular}{|c|c|c|c|c|c|}
\hline \multicolumn{3}{|l|}{ Length of model $x_{\perp}$} & \multicolumn{3}{|l|}{$1000 \mathrm{~km}$} \\
\hline \multicolumn{3}{|l|}{ Amount of extension } & \multicolumn{3}{|l|}{$144 \mathrm{~km}$} \\
\hline \multicolumn{3}{|l|}{ Extension velocity } & \multicolumn{3}{|l|}{$2 \mathrm{~cm} / \mathrm{yr}$} \\
\hline \multicolumn{3}{|c|}{ Vertical resolution in the upper crust } & \multicolumn{3}{|l|}{$1.2 \mathrm{~km}$} \\
\hline \multicolumn{3}{|c|}{ Horizontal resolution } & \multicolumn{3}{|l|}{$2 \mathrm{~km}$} \\
\hline \multicolumn{3}{|c|}{ Temperature at the base of the lithosphere } & \multicolumn{3}{|l|}{$1300{ }^{\circ} \mathrm{C}$} \\
\hline \multicolumn{3}{|c|}{ Radioactive heat production, $\mathrm{H}$} & \multicolumn{3}{|l|}{$1.5 \times 10^{-9} \mathrm{~W} \mathrm{~kg}^{-1}$} \\
\hline \multicolumn{3}{|c|}{ Radiogenic production decay length, $\mathrm{h}$} & \multicolumn{3}{|l|}{$10 \mathrm{~km}$} \\
\hline \multicolumn{3}{|c|}{ Crustal thermal conductivity, $\mathrm{k}$} & \multicolumn{3}{|l|}{$2.5 \mathrm{~W} \mathrm{~K}^{-1} \mathrm{~m}^{-1}$} \\
\hline \multicolumn{3}{|c|}{ Mantle thermal conductivity, $\mathrm{k}_{m}$} & \multicolumn{3}{|l|}{$3.3 \mathrm{~W} \mathrm{~K}^{-1} \mathrm{~m}^{-1}$} \\
\hline \multicolumn{3}{|c|}{ Thermal diffusivity of mantle, $\chi$} & \multicolumn{3}{|l|}{$10^{26} \mathrm{~m}^{2} \mathrm{~s}^{-1}$} \\
\hline \multicolumn{3}{|c|}{ Specific heat, $\mathrm{C}_{\mathrm{n}}$} & \multicolumn{3}{|l|}{$1000 \mathrm{~J} \mathrm{~K}^{-1} \mathrm{~kg}^{-1}$} \\
\hline \multicolumn{3}{|l|}{ Cohesion } & \multicolumn{3}{|l|}{$20 \mathrm{MPa}$} \\
\hline \multicolumn{3}{|l|}{ Moho temperature } & \multicolumn{3}{|l|}{$730{ }^{\circ} \mathrm{C}$} \\
\hline \multicolumn{3}{|c|}{ 2D erosion coefficient, $\mathrm{k}_{w 0}$} & \multicolumn{3}{|l|}{$750 \mathrm{~m}^{2} \mathrm{yr}^{-1}$} \\
\hline & Upper crust & Lower crust & Mantle lithosphere & Weak zone & Asthenosphere \\
\hline Thickness (km) & 20 & 20 & 95 & - & 315 \\
\hline Density, $\rho_{0}\left(\mathrm{~kg} \mathrm{~m}^{-3}\right)$ & 2750 & 2900 & 3330 & 3270 & 3330 \\
\hline $\begin{array}{l}\text { Power law constant, } \\
\mathrm{A}\left(\mathrm{MPa}^{-1 \mathrm{n}} \mathrm{s}^{-1}\right)\end{array}$ & $6.7 \times 10^{-6}$ & $6.3 \times 10^{-2}$ & $7 \times 10^{3}$ & $6.8 \times 10^{3}$ & $7 \times 10^{3}$ \\
\hline $\begin{array}{l}\text { Creep activation } \\
\text { energy, } \mathrm{E}\left(\mathrm{kJ} \mathrm{mol}^{-1}\right)\end{array}$ & 156 & 276 & 520 & 276 & 510 \\
\hline Power law constant, $\mathrm{n}$ & 2.4 & 3.05 & 3 & 4 & 3 \\
\hline
\end{tabular}

thickened crust and the released fluids during subduction created the rheologically weak zone of wet olivine rheology in the lithosphere. The slab roll-back effects inferred in the Pannonian Basin and associated syn-rift extension is represented by constant lateral velocities being imposed at the model boundaries simulating an extensional velocity of $2 \mathrm{~cm} / \mathrm{yr}$ for $7.2 \mathrm{Myr}$. The divergent velocities are set to zero for the subsequent $11 \mathrm{Myr}$, simulating the post-rift phase of basin evolution. The horizontal grid resolution is $2 \mathrm{~km}$ and the vertical grid resolution varies between 1.2 and $3 \mathrm{~km}$. The accuracy of the vertical displacement is thus in the order of 10 metres. We illustrate our thermo-mechanical model results by basement subsidence curves, evolution and thinning of the crustal and lithospheric layers, finite strain images illustrating brittle faults in the upper crust and ductile shear zones in the lower crust and mantle, and the evolution of the temperature field (Figures 2, 3).

\section{Stratigraphic modelling}

Building on reliable tectonic subsidence history, the stratigraphic numerical forward modelling enables the prediction of sedimentary facies distribution and sedimentary transport routes during syn- and post-rift times of basin evolution. Subsidence history is one of the key input parameters in this modelling, and this usually derived from well data (e.g. CsATó et al. 2013). However, in our case the spatial and temporal variation of basement subsidence and uplift values directly comes from the thermo-mechanical modelling. In general two classes of stratigraphic and geo- morphologic forward modelling methods are commonly used. Models of the first class solve locally physical laws at high-resolution with the aim of analysing distinct transport processes (e.g. GrifFITH et al. 2001). Models of the second class that we also use in this study follow basin-scale regional approaches and solve diffusion equations that enable the integrated analysis of erosion, sediment transport and depositional processes. DionisosFlow accounts for the spatial and temporal variation of tectonic vertical motions of the basement, water discharge and sediment supply composed of different sediment classes, compaction, eustasy and different sediment transport processes. Eustasy is modelled by a sine function of sea-level variation with $36 \mathrm{~m}$ half amplitude and $300 \mathrm{kyr}$ time period. This approach combines empirical water and gravity-driven diffusion equations that leads to a sediment transport equation. Furthermore, climatic variations are also simulated by the definition of wet shortterm and dry long-term intervals (BALÁzS et al. 2017b). This modelling approach assumes that during each time step $\sim 30 \%$ of the sediment influx defined at the boundary of the modelling area is characterised by 18 times higher water discharge value during wet short-term than during dry longterm intervals. This discharge ratio between dry and wet periods represents annual precipitation variation and is analysed in a previous study (BALÁzS et al. 2017b). The detailed methodology is described in previous publications (Granjeon \& Joseph 1999, Granjeon 2014).

In this study an area of $150 \times 120 \mathrm{~km}^{2}$ is modelled where two sediment sources are defined at the model corner boundary simulated by kilometre-scale channels transport- 


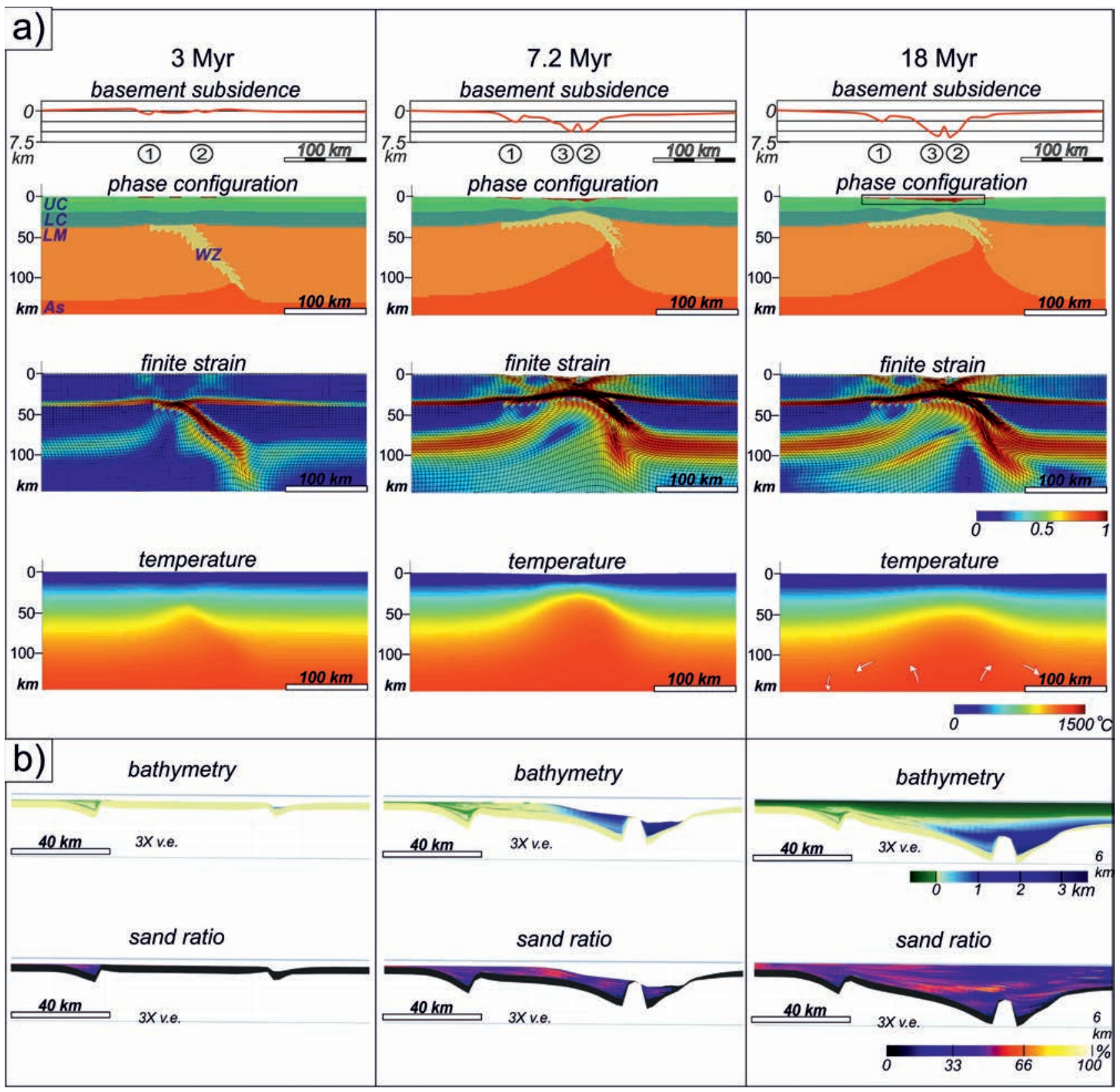

Figure 2. Evolutionary model of the (a) thermo-mechanical and (b) stratigraphic experiments. Results are shown during the syn-rift (3 Myr), at the transition from syn- to post-rift times (7.2 Myr) and after further 10.8 Myr post-rift evolution. Numbers above the phase configuration results show the gradual opening of the sedimentary sub-basins. Dark red colour in the depocenters in the phase configuration panels indicates the sedimentary infill. Bathymetry and sand ratio results are shown in cross sections through the centre of the $3 \mathrm{D}$ model. Note that thick sand bodies deposit in the topsets and in the uppermost part of the foresets of the prograding shelf-margin slopes and further sand portions are also transported at $\sim 40 \mathrm{~km}$ distance from the shore

2. ábra. A termo-mechanikus (a) és rétegtani numerikus modell (b) eredményei a szinrift fázis során ( 3 millió évnél), a szinrift fázis végén (7,2 millió évnél)és a modellezés legvégén. A számok a ,litológiai" fázisösszetétel ábrák fölött az egyes félárkok kinyílásának sorrendjét jelölik, a sötétvörös szín a depocenterekben a lerakódott üledékfázist jelöli. A vízmélység és a durva szemcsés üledékek arányának modelleredményeit $2 D$ szelvényként ábrázoltuk a 3D modell közepén keresztül. Jelentős mennyiségü durva szemcsés üledék a selfperem közelében található, illetve részben a mély vizben a lejtó lábánál, legfeljebb 40 km távolságra a parttól

ing sand and mud fractions (Figure 1, b-c). Furthermore, the eroding footwalls of the depocentres represent internal sources of cobble fraction. Sediment and water discharge values were imposed based on natural examples from rivers such as the Danube (Table II). Each model voxel is built up by the mixture of sand, mud and basement derived cobbles that are visualised by their proportion in Figure 2. The numerical calculation time step is variable from hundreds of years up to $20 \mathrm{kyr}$. The vertical resolution of the experiment varies between tens, up to hundreds of metres. We illustrate and interpret our stratigraphic model results by bathymetry, sand ratio, sedimentation/erosion rate and water current flux of each voxel at certain time steps (see later Figures 26). Based on these attributes we were able to make a differentiation between small-scale coarse-grained deltas evolving in shallow water depth, large-scale mostly fine- 
Table II. Parameters of the 3D stratigraphic forward modelling. For details see GRANJEON (2014) and BALÁzs et al. (2017b). II. táblázat. Rétegtani numerikus modellparaméterek. A modellezés részletes leírása megtalálható korábbi tanulmányokban (GRANJEON 2014, BALAZZS et al. 2017b)

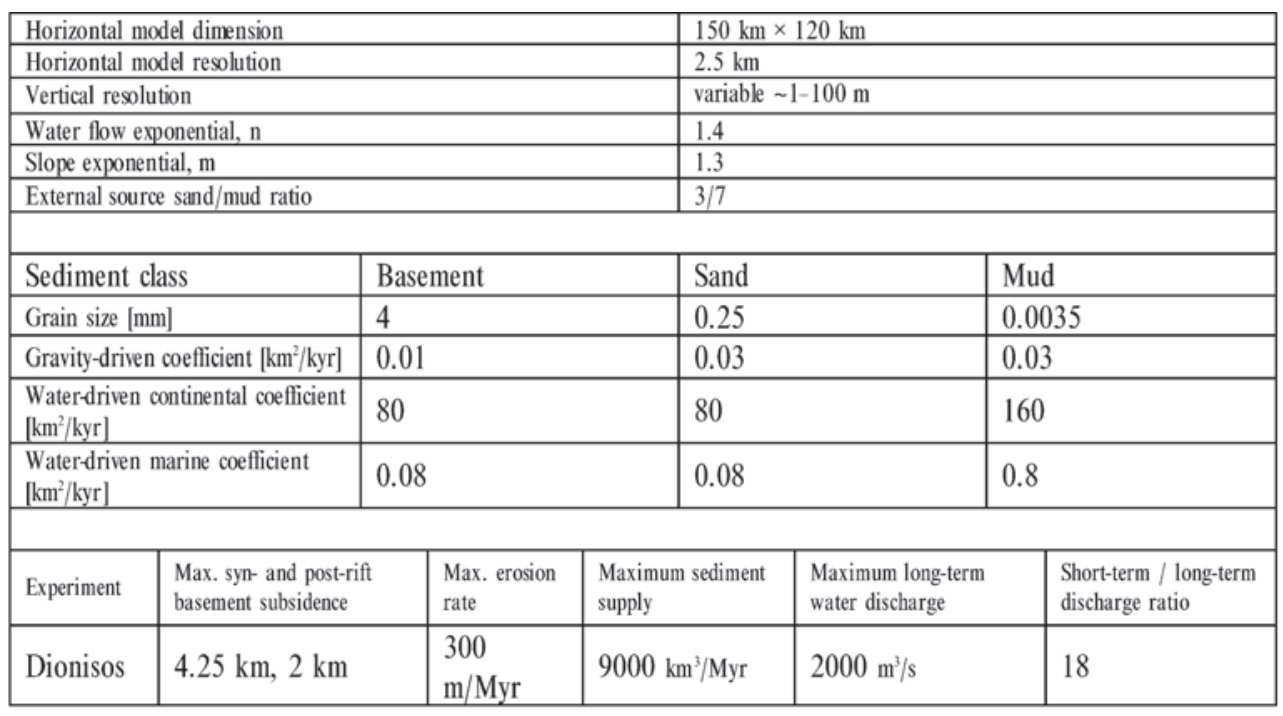

grained shelf-margin slopes, coarse-grained lobes in the deep water and footwall derived fans in the proximity of the eroding footwalls.

\section{Model results}

Our lithospheric-scale numerical experiment shows the formation of an asymmetric extensional basin system, where deformation is mainly controlled by the reactivation of the suture zone that evolves into a lithospheric-scale detachment. This specific scenario is analysed in details in previous studies (BALÁzs et al. 2017a, 2018a); here we only describe the main observations that are essential for the subsequent stratigraphic modelling.

\section{Thermo-mechanical model results}

The first 2 Myr of extension is dominantly controlled by the rapid lithospheric mantle thinning due to strain localisation along the weak zone leading to initial surface uplift (Figures 2, $a$ and 3, $a$ ). Low offset normal faults are initially distributed over a larger area creating limited accommodation space. The continuation of extension is characterised by gradual strain localisation in the crust leading to the development and subsidence of distinct half-graben depocentres and uplift of their footwalls. The first two halfgrabens form near the margin of the underlying suture zone, while younger structures develop towards the centre of the system. Upper crustal thinning is accommodated by ductile lower crustal shearing. Domains of maximum and minimum thinning are opposed in the upper and lower crust. The rapid asymmetric ascent of the asthenosphere is associated with advective redistribution of the weak suture zone beneath the crust, which localises deformation and controls the migration of extensional deformation from the margins to the centre of the overlying crust. This asymmetric rifting thins the crust from the initial $40 \mathrm{~km}$ to $18 \mathrm{~km}$ and the lithospheric mantle from $95 \mathrm{~km}$ to $30 \mathrm{~km}$. After 7.2 Myr when the extensional velocity is set to zero mirroring the termination of syn-rift extension the asthenospheric uprise is attenuated to a more symmetrical geometry controlled by an overall post-rift cooling in the centre and also by the development of small-scale convective cells beneath the basin margins. The lateral heat transport from the asthenospheric anomaly contributes to the uplift and erosion of the basin margins. Sediments are gradually re-distributed in the basin centre resulting in flexural deformation of the weak lithosphere (Figure 2, a). This mechanism enhances differential vertical movements during the "post-rift" phase.

\section{Basin subsidence history}

The above described large-scale tectonic processes lead to a specific scenario of basin subsidence and uplift events that is valid for extensional back-arc domains (for details see BALÁzs et al. 2017a). We have followed the formation and evolution of three distinct half-grabens (i.e. basement subsidence history in Figure 3), where the location of the basins and faults are not pre-imposed, but dynamically formed during extension. The specific back-arc rheology (i.e. initial thick and hot crust) and the hydrated mantle weak zone control a specific basin history (HERON et al. 2016, BALÁZs et al. 2018a). The evolution of the topography indicates an initial gentle uplift event that is followed by diachronous localised hanging-wall subsidence and footwall uplift. Depocentres record variable subsidence rates during their syn-rift extension controlled by the migration of extensional deformation and by the balance between the gradual formation of new faults and shear zones in the upper and lower crust and the fast thinning of the lithospheric mantle (red colour in Figure 3, $c$ indicates shear zones). 
a) Basement subsidence
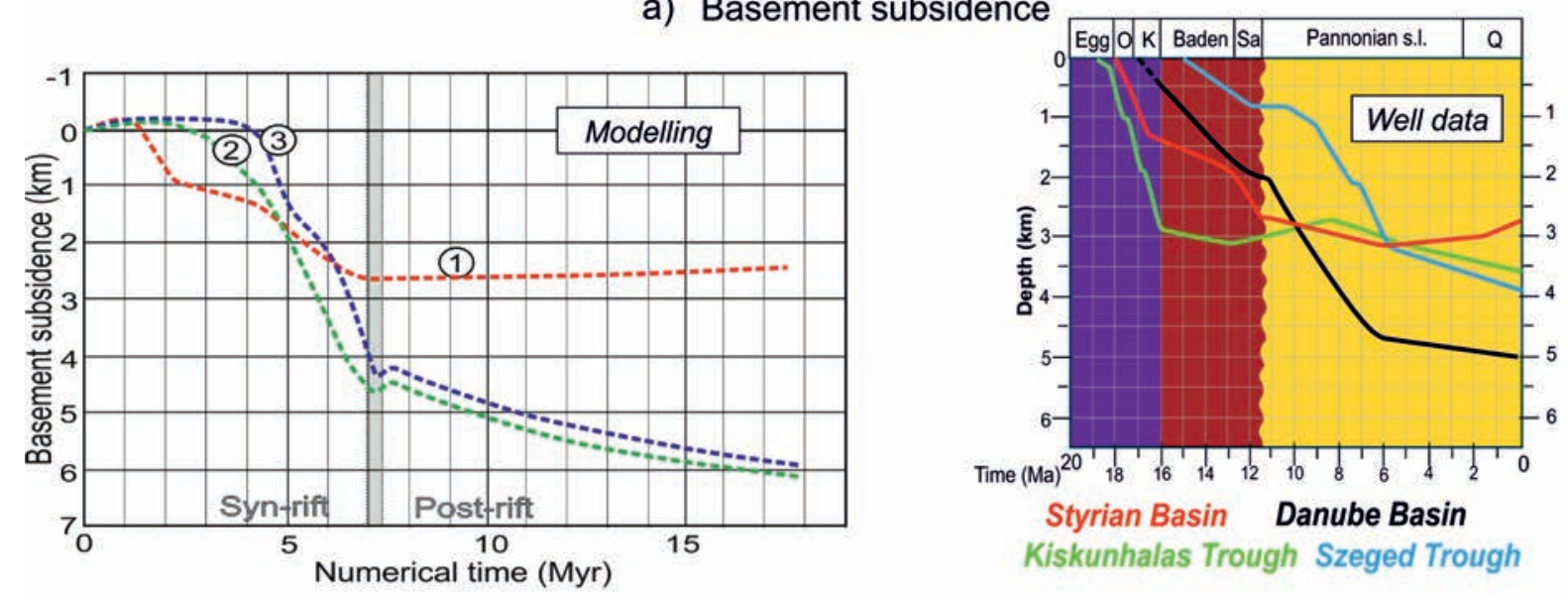

b) Phase configuration

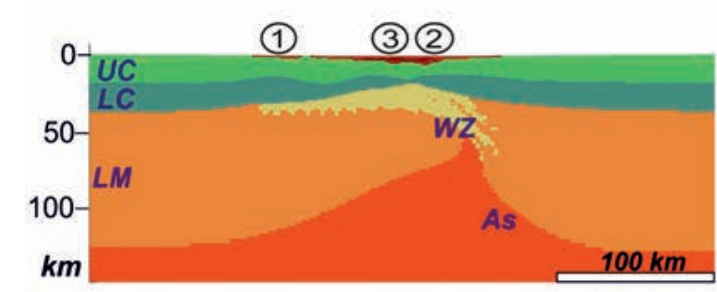

c) Finite strain results

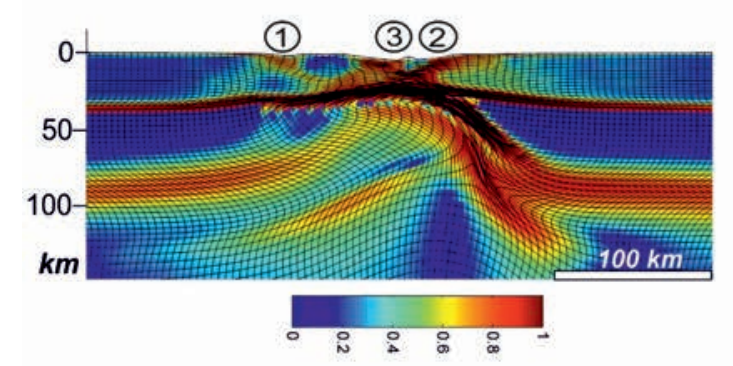

d) Sedimentary architectures during late post-rift times
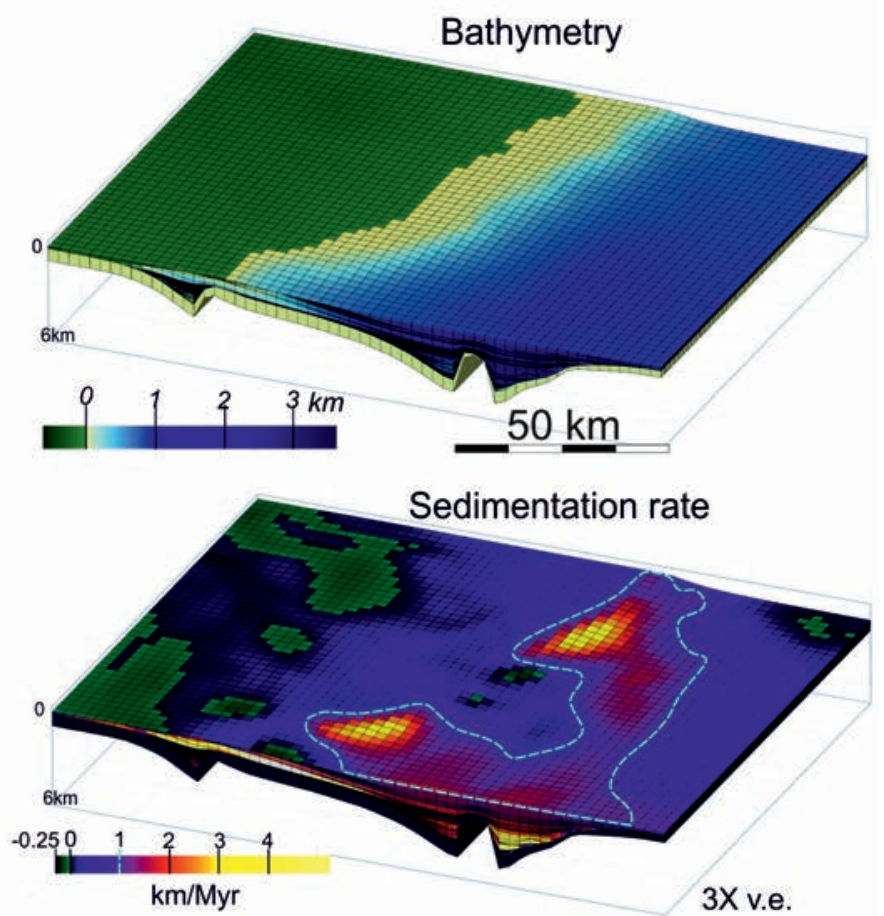

Figure 3. (a) Basement subsidence curves extracted from the thermo-mechanical simulation from the three depocentres (top left) and compared with backstripped well data from the Pannonian Basin depocentres (top right). Numbers 1-3 correspond to the modelled half-grabens also shown in the phase configuration (b) and finite strain results (c). (d) Bathymetric and sedimentation rate results during the post-rift phase (at 10 Myr) in the stratigraphic model. Note the high rates of sedimentation along the active delta systems on the shelf and in the deep basin controlled by high-energy currents contoured by blue dashed line

3. ábra. (a) Aljzatsüllyedési görbék a termo-mechanikus modellezés által számolva (balra) és fúrási adatokból származó értékek a Pannon-medencéböl (jobbra). A számok (1-3) a depocentereket jelölik a fázisösszetétel (b) és deformációs értékek esetén (c). (d) Vizmélység és szedimentációs ráta érékei a poszt-ift fázis során, 10 millió évnél. A magas értékek (kék szaggatott vonallal kiemelve) két aktív deltarendszert jelölnek a selfen, illetve mélyvizi lebenyek fejlödését a mély vizben

A short-lived uplift event at the transition from syn- to post-rift evolution is created by the rapid cessation of extension, which simulates the transition from rapid rollback to collision in the evolution of an extensional back-arc basin, such as the Pannonian Basin. This uplift is controlled by the reorganisation of the stresses in the crust and lithosphere due to the change of the boundary forces; extensional velocity decreases, but the elevated asthenosphere still pushes the surrounding lithosphere and also ductile lower crustal deformation occurs (see also BuROV \& POLIAKOv
2001). The subsequent post-rift subsidence rates are dependent on the inherited crustal/lithospheric thinning and the rate of erosion and sedimentation. Ongoing thermal and flexural effects control the uplift of the margins of the extensional basin system, while post-rift cooling, sediment loading, flexure and gentle lower crustal deformation leads to ca. $2 \mathrm{~km}$ post-rift subsidence of the basin centre (Figure 3). Thermo-mechanical modelling infers that differential vertical movements are enhanced by lithospheric flexure linked to erosional unloading of the margins and sedi- 
mentary loading of the thermally weakened lithosphere in the centre. Note that the oldest half-graben (no. 1 in Figure 2 and 3 ) is also affected by post-rift uplift during this late stage, while subsidence continues in younger depocentres in the centre of the basin system.

\section{Stratigraphic model results}

High-resolution stratigraphic evolution of the syn-rift depocentres and post-rift environments are modelled by DionisosFlow (GRANJEON \& JOSEPH 1999, GRANJEON 2014) using the basement subsidence history generated by Flamar (Figure 3). During early syn-rift evolution significant accommodation space is created only in the first halfgraben that is fed by the external sediment source defined at the model boundary, creating alluvial to shallow delta deposits. Furthermore, footwall derived fans are deposited at the proximity of its boundary fault (Figure 2, b and 4). From 3 Myr the second half-graben records higher subsidence rates, from $4 \mathrm{Myr}$ the third sub-basin evolves in between the first two (Figure 3, a). By the end of syn-rift times at 7.2 Myr the first half-graben is filled mostly by shallow water deltas, while deep water sediments only deposited between 6-7 Myr, when subsidence rates reach their highest values. The second sub-basin located farther from the external source evolves as a starving basin during the syn-rift phase and is also separated by a more proximal third half-graben. Sedimentary transport routes concentrate towards this proximal depocentre preventing sedimentation in the distal half-graben, where only footwallderived fans are deposited (Figure 2, b and 4). The separating footwall in the middle of the model area gradually subsides beneath the water-level; only from 6 Myr onwards high energy currents simulating turbidity flows reach the second depocentre (Figure 4).

At the beginning of post-rift evolution 1-1.75 km water depth has been inherited from the prior syn-rift subsidence for the second and third depocentres (Figure 2), while the first half-graben area only records alluvial deposition (Figure 4 ). The latter water depth gradually decreased due to progradation of a large delta and shelf-margin slope system (Figure 3, d). Coarse-grained sediments are deposited in the shelf and at the toe of slope, while the shelf-margin slope remains mainly fine-grained (Figure 2). Sand lobes are transported at larger distances during periods of wet climate,

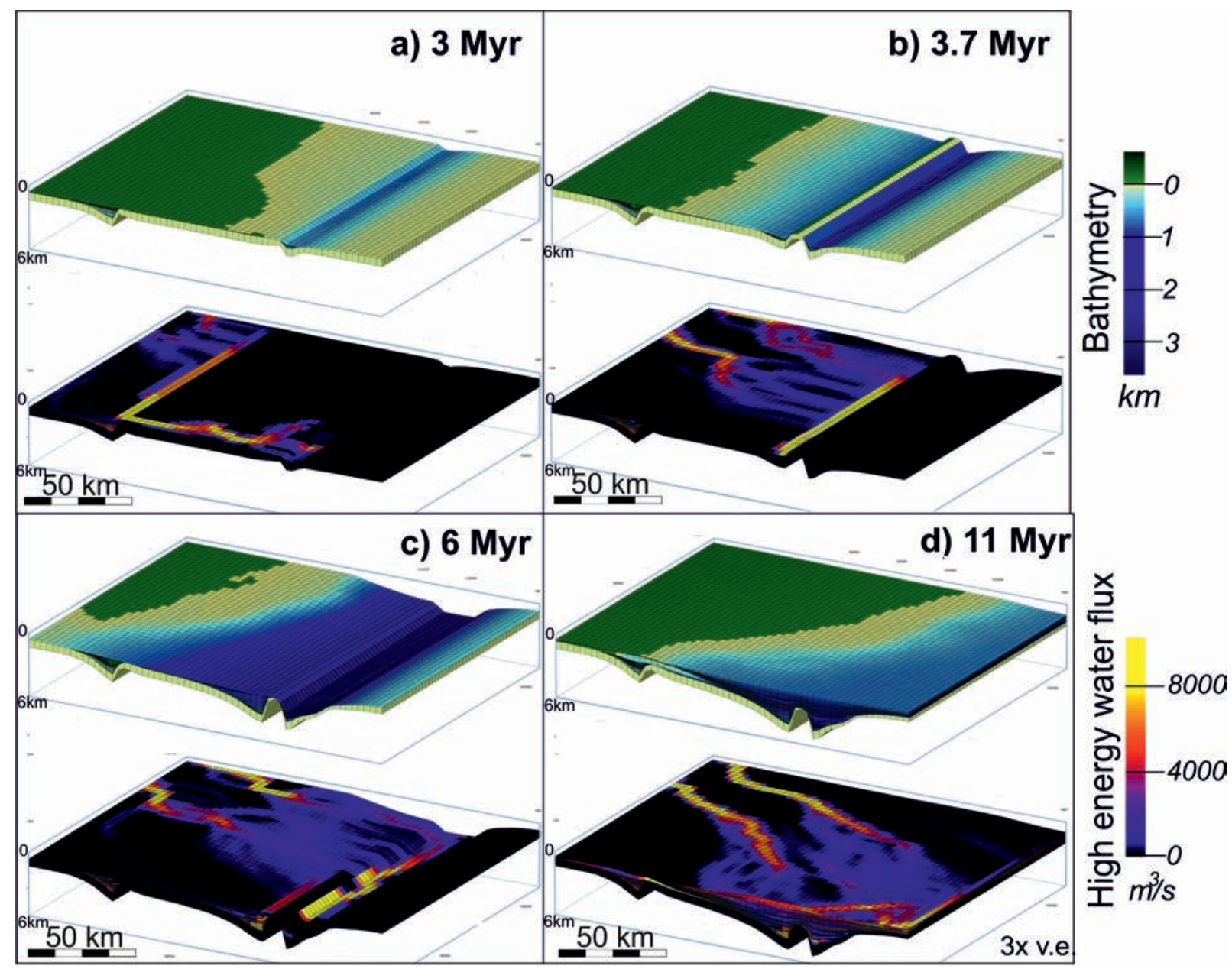

Figure 4. (a-d) Bathymetric and water flow flux evolution in the stratigraphic model

4. ábra. (a-d) Vizmélység és vizáramlási ráta modelleredmények a rétegtani modellezés során 

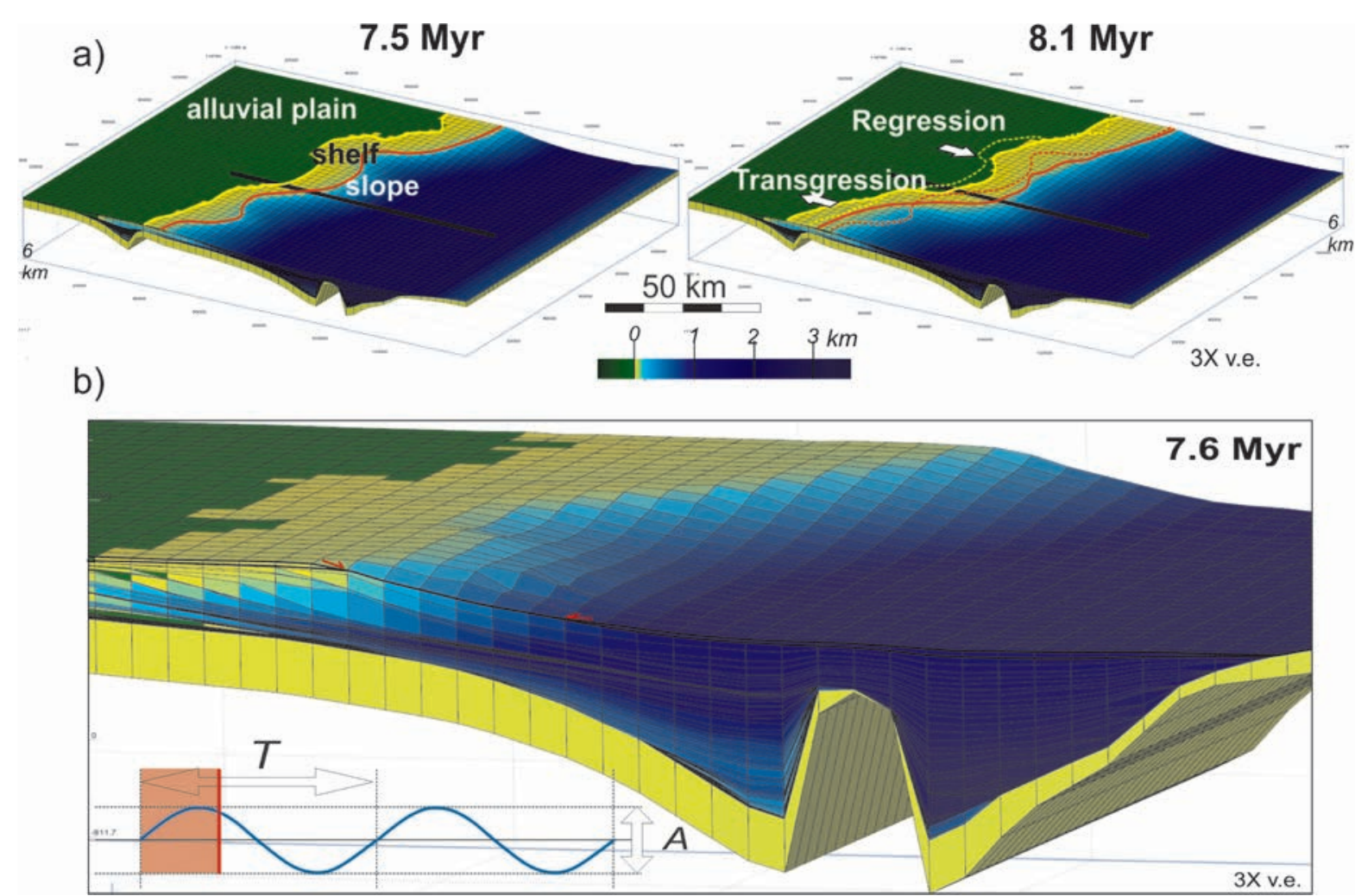

Figure 5. Bathymetry snapshots showing the overall late post-rift regression. (a) Oblique top-view figures show coeval transgression and regression along the shelf due to laterally variable sedimentation rate. Yellow and orange colours indicate the shoreline and the shelf-edge at $7.5 \mathrm{Myr}$ (left) and 8.1 Myr (right), respectively. Dashed lines in the right figure indicate the older lines correspond to $7.5 \mathrm{Myr}$ (numerical time). (b) Zoomed figure indicate the stacking pattern and reflection terminations at highstand condition

5. ábra. Vizmélység-modell eredmények a medence posztrift feltöltödése során. (a) Egyidejü transzgresszió és regresszió kialakulása a selfen laterálisan változó szedimentációs ráta által. Míg az üledékforráshoz közelebbi selfterületen mind a part (sárga vonal), mind a selfperem (narancs vonal) a medence irányába mozdul el, addig a forrástól távolabb ekkor a selfen nincsen aktív delta, amely nagy mennyiségü üledéket szállítana, így itt a partvonal a szárazföld felé mozdul el. (b) Kinagyitott részlet a modell közepéböl, amely mutatja egy kis delta lelapolódását a selfen és a mély vizben kialakuló tengeri rálapolódást a lejtőre

when water discharge values are increased (Figure 3, d). Lateral migration of the active delta system on the shelf and lobe switching creates onlap surfaces without changing the subsidence rate or changing the boundary water and sediment discharge (VAN DIJK et al. 2009, BALÁZs et al. 2017b). Our modelling also shows coeval transgression and regression controlled by the lateral variability of sedimentation rate along the shelf due to the migration of the delta system (Figure 5, a). Eustatic water-level changes strongly modifies the overall stratal stacking pattern (Porebski \& SteEl 2003, HeNRIKSEN et al. 2011) creating coastal and marine onlap and downlap terminations and also determines the shelf morphology (Figure 5, b). Finally, between 7.2 and $12 \mathrm{Myr}$ (numerical time), this system progrades ca. $100 \mathrm{~km}$ leading to alluvial sedimentation in the entire model domain.

\section{Comparison with observations from the Pannonian Basin}

The joint thermo-mechanical and stratigraphic model results provide critical insights into the kinematics of extension and the sedimentary architecture of extensional basins floored by continental crust and mainly sourced by sediments from one dominant direction.

The Pannonian Basin of Central Europe (Figure 6 ) is a continental back-arc basin (HoRVÁTH \& ROYDEN 1981), where the ca. $250 \mathrm{~km}$ of Early to Late Miocene extension (BALÁzS et al. 2017a) was controlled by subduction and slab roll-back along the Carpathians and Dinarides (HoRvátH et al. 2015, MATENCO et al. 2016). Extension affected a thick and hot orogenic crust and a heterogeneous lithosphere with inherited suture zones (CSONTOS \& VÖRÖS 2004, USTASZEWSKI et al. 2010) leading to asymmetric extensional evolution (TARI et al. 1999, BALÁzs et al. 2018a). In agreement with our modelling extensional deformation migrated from the basin margins towards its centre, creating half-grabens with sedimentary thicknesses up to $7 \mathrm{~km}$ (Figure 3, a). Oldest depocentres are located today at the periphery of the larger Pannonian Basin system, that are often characterised by ca. $0.1 \mathrm{~km} / \mathrm{Myr}$ postrift uplift, such as the Styrian Basin (EBNER \& SASCHENHOFER 1995), the westernmost Danube Basin, Sava Basin, the East Slovakian Basin or the subbasins near the Apuseni Mountains margin (Figure 6). This long wavelength deformational pattern infers the role of deep Earth processes. Our numerical modelling does not include shortening or contractional deformation. The uplift of the basin margins is caused by the 


\section{a $16.6 \mathrm{Myr}$}
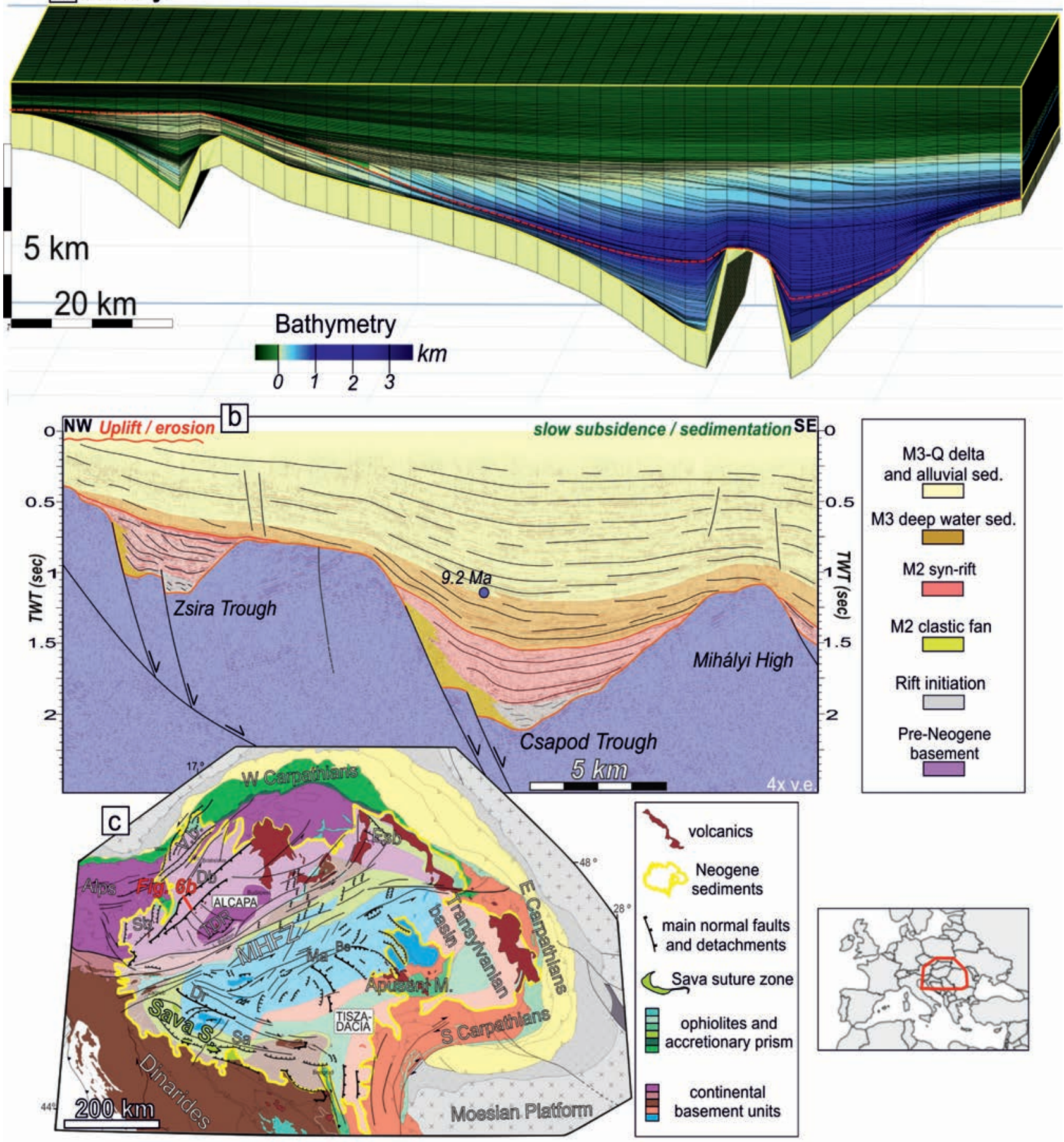

Figure 6. Comparison of the model results with seismic data from the Danube Basin. (a) Final palaeo-water depth result of the experiments. Note the contrasting syn- and post-rift sedimentary thicknesses in the depocentres and the different stratigraphic geometries, unconformities and correlative conformities. Red line indicates the horizon bounding syn- and post-rift times. (b) Interpreted reflection seismic section from the western part of the Pannonian Basin. Orange line indicates the base Neogene unconformity, red line indicates the base of the Late Miocene (Pannonian) sediments. (c) Tectonic map of the Pannonian Basin indicating the main Miocene extensional structures. $\mathrm{Db}=$ Danube Basin, $\mathrm{TDR}=$ Transdanubian Range, $\mathrm{Vb}=\mathrm{Vienna} \mathrm{Basin}, \mathrm{Sa}=\mathrm{Sava}$ Subbasin, $\mathrm{Dr}$ = Dráva Subbasin, $\mathrm{Ki}=$ Kiskuhalas Subbasin, $\mathrm{Ma}=$ Makó Subbasin, $\mathrm{Be}=$ Békés Subbasin, $\mathrm{ESb}=$ East Slovakian Basin, $\mathrm{Sb}=\mathrm{Styrian}$ Subbasin . Note the suture zones at the Dinaridic and Carpathian margins of the basin. Pre-Neogene basement map is modified after ScHMID et al. (2008)

6. ábra. Modelleredmények összevetése értelmezett szeizmikus szelvénnyel a Kisalföldröl. (a) Végsö vízmélységfejlödés a numerikus modellezés végén. A piros horizont azt az idôpillanatot képezi le, amikor a szinrift extenziós sebességek nullára csökkentek. (b) A szeizmikus szelvényen értelmezett narancs horizont a miocén üledékek talpán található unkonformitást, a piros horizont a pannóniai talpat jelöli. (c) A Kárpát-Pannon térség tektonikai térképe a föbb miocén szerkezetekkel. $D b=$ Duna-medence $/$ Kisalföld, $T D R=$ Dunántúli-középhegység, $V b=$ Bécsi-medence, $S a=$ Száva-árok, Dr = Dráva-árok, Ki $=$ Kiskunhalasi-árok, Ma $=$ Makói-árok, $B e=$ Békési-medence, $S b=$ Stájer-medence. A medence kialakulásában szerepet játszott a dinári és kárpáti peremeken található, ellentétes polaritású két örökölt szutúra (USTASZEWSKI et al. 2010, BALÁZS et al. 2018a). A preneogén medencetérkép SCHMID et al. (2008) alapján lett módosítva 
lateral heat transport from the asthenospheric anomaly and by lithospheric elastic flexure linked to erosion of the basin margins and sediment redistribution in the centre (BALÁzs et al. 2017a). In the case of the Pannonian Basin, neotectonic inversion and positive reactivation of Miocene normal faults accentuates the uplift of the south-western margin of the basin and increases the amplitude of basin flexure (HORVÁTH \& Cloetingh 1996, BADA et al. 2007, Dombrádi et al. 2010).

Our stratigraphic model results show fairly good similarity with seismic sections from the Pannonian Basin (Figure 6). Syn-rift depocentres that were located in the proximity of their source regions like the Zsira Trough in the Danube Basin (Figure 6) or the Kiskunhalas Trough in the Great Hungarian Plain (BALÁzs et al. 2017b) show similar tectonics controlled transgressive-regressive cycles like our modelled half-graben (no. 1 in Figure 2 and 4). However, depocentres that were located at larger distance from the main sediment sources during their synrift evolution, like the Late Miocene Makó Trough (Figure 6) were probably characterised by $1-1.6 \mathrm{~km}$ palaeo-bathymetry as sedimentation did not take pace with the fast subsidence during their rift climax (SzTANó et al. 2013, BALÁzS et al. 2017b). In agreement with seismic and well data from the post-rift fill of the basin we simulated the progradation of a large-scale shelf-margin slope clinoforms connecting the shelf and the deep basin and small prograding deltas on the shelf (Figure 5; UHRIN \& Sztanó 2011, Magyar et al. 2013, Sztanó et al. 2013). Similar to our model results, the decompacted height of such Pannonian clinoforms is ca. 600-1 000 metres with a dip angle of ca. 3-8 degrees (BALÁzs et al. 2018b). Clinoforms are overlying turbidites and deep water marls deposited in even larger water depths up to 1600 meters (cf., BALÁZs et al. 2017b). We simulated unconformities within the post-rift infill caused by auto-cyclic processes, such as lobe switching as observed on seismic data imaging the Pannonian sediments (UHRIN \& SzTANó 2011, BALÁZs et al. 2017b). Finally, our modelled basin architecture shows the overall syncline geometry in the basin centre resembling the ongoing subsidence, gentle anticline geometries above buried footwalls created by differential compaction and erosional unconformities and thinning of the post-rift strata towards the basin margins controlled by their post-rift uplift (Figure 3 and 6 ).

\section{Conclusions}

We have conducted a new numerical modelling procedure by combining the 2D thermo-mechanical code Flamar (BUROV \& YAMATO 2008) and the 3D stratigraphic code DionisosFlow (GRANJEON 2014). Its application yields new insights into the links between deep Earth and surface processes shaping sedimentary basins. We have simulated the asymmetric extension of a heterogeneous lithosphere containing an inherited suture zone. Within the basin, domains of minimum upper crustal thinning are affected by higher values of lower crustal thinning due to ductile lower crustal flow. This infers that areas without observed major brittle faults, such as the Transdanubian Range or the Apuseni Mountains are also characterised by significantly thinner crust than their pre-rift architecture had. We have analysed the subsidence of a system of half-grabens. Their syn- and post-rift subsidence and uplift rates and thermal history is connected to their position with respect to the inherited suture zone, such as the Sava Zone of the Dinaridic margin. This asymmetric extensional evolution is extracted for the subsequent stratigraphic and further basin modelling studies.

The stratigraphic model simulated the sedimentary facies distribution in the extensional basin system. Thick coarse-grained sediments are deposited during the rift initiation phase associated with low subsidence rate and during the rift climax period along the boundary faults and in the hanging wall flank of the basins fed by the eroding footwall and delta systems. During the post-rift phase sand mainly accumulates on the shelf and at the toe of slope. High energy current during wet climate, i.e. turbidity flows can transport sand bodies at larger distances. We modelled and analysed transgressive-regressive sedimentary cycles controlled by tectonics, eustasy and sedimentary auto-cyclic processes, such as lobe switching. Our modelling also yields large palaeo-water depth variations between and in the depocentres. Low-order tectonic-driven cycles developed in the half-graben in the proximity of the sedimentary source, while other depocentres remained underfilled during their syn-rift evolution, such as the Late Miocene Makó Trough.

The necessary next advance in a similar tectonosedimentary model needs to be built on the integration of 3D thermo-mechanical methods with the stratigraphic approach. For the case of the Pannonian Basin, the 3D modelling of further subduction dynamics will be crucial. Such a challenging scientific goal for the development of a fully coupled 3D numerical method that can bridge the gap between the different timescales of deep Earth and sedimentary processes will provide further progress in understanding the dynamics of extensional basins.

\section{Acknowledgements}

We dedicate this article to the memory of Frank HoRVÁtH, who largely improved our knowledge on the formation and evolution of the Pannonian Basin. All numerical simulations presented in this paper have been conducted at Utrecht University, the Netherlands. Katharina VOGT and Thomas FRANÇOIS are acknowledged for their kind support in numerical modelling. Orsolya SzTANó and László FODOR are thanked for the fruitful discussions. Alexander KOPTEV and Thomas FRANÇOIS are thanked for their helpful and constructive comments. The stratigraphic numerical code used in this study can be requested by contacting Beicip-Franlab (www.beicip.com). We thank Beicip-Franlab for providing an academic license for DionisosFlow. 


\section{References — Irodalom}

Bada, G., Horváth, F., Dövényi, P., Szafián, P., Windhoffer, G. \& Cloetingh, S. 2007: Present-day stress field and tectonic inversion in the Pannonian Basin. — Global and Planetary Change 58, 165-180. https://doi.org/10.1016/j.gloplacha.2007.01.007

Balázs, A., Burov, E., Matenco, L., Vogt, K., Francois, T. \& Cloetingh, S. 2017a: Symmetry during the syn- and post-rift evolution of extensional back-arc basins: the role of inherited orogenic structures. — Earth and Planetary Science Letters 462, 86-98. https://doi.org/10.1016/j.epsl.2017.01.015

Balázs, A., Granjeon, D., Matenco, L., Sztanó, O. \& Cloetingh, S. 2017b: Tectonic and climatic controls on asymmetric half-graben sedimentation: Inferences from 3-D numerical modeling. — Tectonics 36, 2123-2141. https://doi.org/10.1002/2017TC004647

Balázs, A., Matenco, L., Vogt, K., Cloetingh, S. \& Gerya, T. 2018a: Extensional polarity change in continental rifts: inferences from 3D numerical modeling and observations. - Journal of Geophysical Research: Solid Earth 123, 8073-8094. https://doi.org/ 10.1029/2018jb015643

Balázs, A., Magyar, I., Matenco, L., Sztanó, O., Tőkés, L. \& Horváth, F. 2018b: Morphology of a large paleolake: analysis of compaction in the Miocene-Quaternary Pannonian Basin. — Global and Planetary Change 171, 134-147. https://doi.org/10.1016/ j.glopl acha.2017.10.012

Békési, E., Lenkey, L., Limberger, J., Porkoláb, K., Balázs, A., Bonté, D., Vrijlandt, M., Horváth, F., Cloetingh, S. \& van Wees, J-D. 2017: Subsurface temperature model of the Hungarian part of the Pannonian Basin. _ Global and Planetary Change 171, 4864. https://doi.org/10.1016/j.glopl acha.2017.09.020

Bialas, R. \& BUCK, W. R. 2009: How sediment promotes narrow rifting: Application to the Gulf of California. — Tectonics 28, TC4014, https://doi.org/10.1029/2008TC002394

BuRov, E. 2007: The role of gravitational instabilities, density structure and extension rate in the evolution of continental margins. Special Publications of the Geological Society of London 282, 139-156. https://doi.org/10.1144/sp282.7

Burov, E. \& Poliakov, A. 2001: Erosion and rheology controls on syn and post-rift evolution: verifying old and new ideas using a fully coupled numerical model. — Journal of Geophysical Research 106, 16461-16481.

Burov, E. \& YAMATO, P. 2008: Continental plate collision, P-T-t-z conditions and unstable vs. stable plate dynamics: Insights from thermo-mechanical modelling. — Lithos 103, 178-204. https://doi.org/10.1016/j.lithos.2007.09.014

CARTER, N. L. \& TSEnN, M. C. 1987: Flow properties of continental lithosphere. - Tectonophysics 136, 27-63.

CHOPRA, P. N. \& PATERSON, M. S. 1984: The role of water in the deformation of dunite. - Journal of Geophysical Research 89, 78617876. https://doi.org/10.1029/jb089ib09p07861

Cundall, P. A. 1989: Numerical experiments on localization in frictional materials. — Archive of Applied Mechanics 59, $148-159$. https://doi.org/ 10.1007/bf00538368

Csató, I., Granjeon, D., Catuneanu, O. \& Baum, G. R. 2013: A three-dimensional stratigraphic model for the Messinian crisis in the Pannonian Basin, eastern Hungary. — Basin Research 25, 121-148. https://doi.org/10.1111/j.1365-2117.2012.00553.x

Csató, I., CATuneAnu, O. \& GRANJEON, D. 2014: Millennial-scale sequence stratigraphy: numerical simulation with Dionisos. — Journal of Sedimentary Research 84, 394-406. https://doi.org/10.2110/jsr.2014.36

Csontos, L. \& VöRÖs, A. 2004: Mesozoic plate tectonic reconstruction of the Carpathian region. - Palaeogeography, Palaeoclimatology, Palaeoecology 210, 1-56. https://doi.org/10.1016/j.palaeo.2004.02.033

Dombrádi, E., Sokoutis, D., BadA, G., Cloetingh, S. \& Horváth, F. 2010: Modelling recent deformation of the Pannonian lithosphere: Lithospheric folding and tectonic topography. — Tectonophysics 484, 103-118. https://doi.org/10.1016/j.tecto.2009.09.014

EBNER, F. \& SASCHENHOFER, R. F. 1995: Palaeogeography, subsidence and thermal history of the Neogene Styrian Basin (Pannonian basin system, Austria). — Tectonophysics 242, 133-150. https://doi.org/10.1016/0040-1951(94)00155-3

Fodor, L., Csontos, L., BadA, G., GyôRfi, I. \& Benkovics, L. 1999: Tertiary tectonic evolution of the Pannonian basin system and neighbouring orogens: a new synthesis of paleostress data. — In: Durand, B., Jolivet, L., Horváth, F. \& SÉranne, M. (eds): The Mediterranean Basins: Tertiary Extension Within the Alpine Orogene. Blackwell Sciences, Special Publications of the Geological Society of London, Oxford, 295-334. https://doi.org/10.1144/gsl.sp.1999.156.01.15

Françols, T., Burov, E., Meyer, B. \& Agard, P. 2013: Surface topography as key constraint on thermo-rheological structure of stable cratons. — Tectonophysics 602, 106-123. https://doi.org/10.1016/j.tecto.2012.10.009

François, T., Koptev, A., Cloetingh, S., Burov, E. \& Gerya, T. 2018: Plume-lithosphere interactions in rifted margin tectonic settings: Inferences from thermo-mechanical modelling. — Tectonophysics 746, 138-157. https://doi.org/10.1016/j.tecto.2017.11.027

GerYA, T. V. 2010: Introduction to numerical geodynamic modelling. — Cambridge, UK: Cambridge University Press, 345 p. https://doi.org/10.1017/CBO9780511809101

GRANJEON, D. 2014: 3D forward modelling of the impact of sediment transport and base level cycles on continental margins and incised valleys. —International Association of Sedimentologist Special Publication 46, 453-472. https://doi.org/10.1002/9781118920435.ch16

GranjeOn, D. \& JosePh, P. 1999: Concepts and applications of a 3-D multiple lithology, diffusive model in stratigraphic modeling. — In: Harbaugh, J. W., Watney, X. L., Rankey, E. C., Slingerland, R., Goldstein, R. H. \& Franseen, E. K. (eds): Numerical experiments in stratigraphy. Recent advances in stratigraphic and sedimentologic computer simulations 62, 197-210. Tulsa, Society for Sedimentary Geology. https://doi.org/10.2110/pec.99.62.0197

Griffiths, C. M., Dyt, C., Paraschivoiu, E. \& LiU, K. 2001: Sedsim in hydrocarbon exploration. — In: Merriam, D. \& Davis, J. C. (eds): Geologic modeling and simulation. New York: Kluwer Academic. 71-97. https://doi.org/10.1007/978-1-4615-1359-9_5

Henriksen, S., Helland-Hansen, W. \& Bullimore, S. 2011: Relationship between shelfedge trajectories and sediment dispersal along depositional dip and strike: a different approach to sequence stratigraphy. — Basin Research 23, 3-21. https://doi.org/10.1111/j.13652117.2010.00463.x 
Heron, P. J., Pysklywec, R. N. \& Stephenson, R. 2016: Lasting mantle scars lead to perennial plate tectonics. - Nature Communications 7, 11834. https://doi.org/10.1038/ncomms11834

Horváth, F. \& Cloetingh, S. 1996. Stress-induced late-stage subsidence anomalies in the Pannonian basin. — Tectonophysics 266, 287300. https://doi.org/10.1016/s0040-1951(96)00194-1

Horváth, F. \& FacCenna, C. 2011: Central Mediterranean mantle flow system and the formation of the Pannonian basin. — Geophysical Research Abstracts 13, EGU2011-8894-2

Horváth, F. \& RoYden, L. 1981: Mechanism for formation of the intra-Carpathian basins: a review. — Earth Evolution Sciences 1, $307-316$.

Horváth, F., Musitz, B., Balázs, A., Végh, A., Uhrin, A., NÁdor, A., Koroknai, B., Pap, N., Tóth, T. \& Wórum, G. 2015. Evolution of the Pannonian basin and its geothermal resources. - Geothermics 53, 328-352. https://doi.org/10.1016/j.geothermics. 2014.07.009

Horváth, F., DövÉNYI, P., SZALAY, Á. \& RoYdEn, L. H. 1988: Subsidence, thermal and maturation history of the Great Hungarian Plain. — In: Royden, L. H. \& Horváth, F. (eds): The Pannonian Basin. — American Association of Petroleum Geologists Memoirs 45, 355-372.

Huet, B., Pourhiet, L. L., Labrousse, L., Burov, E. \& Jolivet, L. 2011: Post-orogenic extension and metamorphic core complexes in a heterogeneous crust, the role of pre-existing nappes. — Geophysical Journal International 184, 611-625. https://dx.doi.org/10.1111/ j.1365-246X.2010.04849.x

Juhász, Gy., Pogácsás, Gy., Magyar, I. \& VAKarcs, G. 2007: Tectonic versus climatic control on the evolution of fluvio-deltaic systems in a lake basin, Eastern Pannonian Basin. — Sedimentary Geology 202, 72-95. https://doi.org/10.1016/j.sedgeo.2007.05.001

Koptev, A., Burov, E., Gerya, T., Leroy, S., CAlais, E. \& Jolivet, L. 2018: Plume-induced continental rifting and breakup in ultra-slow extension context: Insights from 3D numerical modeling. — Tectonophysics 746, 121-137. https://doi.org/10.1016/ j.tecto.2017.03.025

Lenkey, L., Dövenyi, P., Horváth, F. \& Cloetingh, S. A. P. L. 2002: Geothermics of the Pannonian Basin and its bearing on neotectonic. — In: Cloetingh, S., Horváth, F., BadA, G. \& LAnkreijer, A. (eds): Neotectonics and Surface Processes: the Pannonian Basin and Alpine/Carpathians System. European Geosciences Union, Stephan Mueller Special Publications 3, 29-40. https://doi.org/ 10.5194/smsps-3-29-2002

Magyar, I., Radivojević, D., Sztanó, O., Synak, R., UjszÁszi, K. \& Pócsik, M. 2013: Progradation of the paleo-Danube shelf margin across the Pannonian Basin during the Late Miocene and Early Pliocene. - Global and Planetary Change 103, $168-173$. https://doi.org/10.1016/j.gloplacha.2012.06.007

Matenco, L., Munteanu, I., Ter Borgh, M., Stanica, A., Tilita, M., Lericolais, G., Dinu, C. \& Oaie, G. 2016: The interplay between tectonics, sediment dynamics and gateways evolution in the Danube system from the Pannonian Basin to the western Black Sea. Science of the Total Environment 543, 807-827. https://doi.org/10.1016/j.scitotenv.2015.10.081

McKenZIE, D. 1978: Some remarks on the development of sedimentary basins. — Earth and Planetary Science Letters 40, $25-32$. https://doi.org/10.1016/0012-821x(78)90071-7

Nagymarosy, A. \& HÁmor, G. 2012: Genesis and evolution of the Pannonian Basin. — In: HAAS, J. (ed.): Geology of Hungary. Regional Geology Reviews, Springer, 149-200. https://doi.org/10.1007/978-3-642-21910-8_3

Poliakov, A. N. B., Cundall, P., Podladchilov, Y. \& Laykhovsky, V. 1993: An explicit inertial method for the simulation of viscoelastic flow: An evaluation of elastic effects on diapiric flow in two or three-layers models. - In: STONE, D. B. \& RUNCORN, S. K. (eds): Flow and Creep in the Solar System: Observations, Modelling and Theory, Dyn. Modell. Flow Earth Planet Series 175-195. https://doi.org/10.1007/978-94-015-8206-3_12

PorebsKI, S. J. \& STEEL, R. J. 2003: Shelf-margin deltas: their stratigraphic significance and relation to deepwater sands. - EarthScience Reviews 62, 283-326. https://doi.org/10.1016/s0012-8252(02)00161-7

Ranalli, G. \& MurPhy, D. C. 1987: Rheological stratification of the lithosphere. - Tectonophysics 132, 281-295. https://doi.org/ 10.1016/0040-1951(87)90348-9

RoYdEN, L. \& KEEN, C. 1980: Rifting process and thermal evolution of the continental margin of eastern Canada determined from subsidence curves. - Earth and Planetary Science Letters 51, 343-361. https://doi.org/10.1016/0012-821 x(80)90216-2

Schmid, S., Bernoulli, D., Fügenschuh, B., Matenco, L., Schefer, S., Schuster, R., Tischler, M. \& Ustaszewski, K. 2008: The Alpine-Carpathian-Dinaridic orogenic system: correlation and evolution of tectonic units. - Swiss Journal of Geosciences 101, 139-183. https://doi.org/10.1007/s00015-008-1247-3

SCHLAGER, W. 1993: Accommodation and supply — A dual control on stratigraphic sequences. — Sedimentary Geology 86, 111-136.

Sclater, J. G., Royden, L., Horváth, F., Burchfiel, B. C., SEMken, S. \& StegenA, L. 1980: The formation of the intra-Carpathian basins as determined from subsidence data. — Earth and Planetary Science Letters 51, 139-162. https://doi.org/10.1016/0012$821 \times(80) 90262-9$

Sztanó, O., Szafián, P., Magyar, I., Horányi, A., Bada, G., Hughes, D. W., Hoyer, D. L. \& Wallis, R. J. 2013: Aggradation and progradation controlled clinothems and deep-water sand delivery model in the Neogene Lake Pannon, Makó Trough, Pannonian Basin, SE Hungary. — Global and Planetary Change 103, 149-167. https://doi.org/10.1016/j.gloplacha.2012.05.026

Tari, G., Dövényi, P., Dunkl, I., Horváth, F., Lenkey, L., Stefanescu, M., Szafián, P. \& Tóth, T. 1999: Lithospheric structure of the Pannonian basin derived from seismic, gravity and geothermal data. — In: Durand, B., Jolivet, L., Horváth, F. \& SerRane, M. (eds): The Mediterranean Basins: Extension Within the Alpine Orogen. Geological Society (London) Special Publication 156, 215250. https://doi.org/10.1144/gsl.sp.1999.156.01.12

UHRIN, A. \& SzTANó, O. 2011: Water-level changes and their effect on deepwater sand accumulation in a lacustrine system: a case study from the Late Miocene of western Pannonian Basin, Hungary. — International Journal of Earth Sciences 101, 1427-1440. http://dx.doi.org/10.1007/s00531-011-0741-4

Ustaszewski, K., Kounov, A., Schmid, S., Schaltegger, U., Krenn, E., Frank, W. \& Fügenschuh, B. 2010: Evolution of the Adria- 
Europe plate boundary in the northern Dinarides: From continent-continent collision to back-arc extension. —Tectonics 29, TC6017, https://doi.org/10.1029/2010TC002668

van Dijk, M., Postma, G. \& Kleinhans, M. G. 2009: Autocyclic behaviour of fan deltas: An analogue experimental study. Sedimentology 56, 1569-1589. https://doi.org/10.1111/j.1365-3091.2008.01047.x

WilKs, K. R. \& CARTER, N. L. 1990: Rheology of some continental lower crust. - Tectonophysics 182, 55-77. https://doi.org/ 10.1016/0040-1951(90)90342-6

Manuscript recieved: 15/06/2019 